\title{
Evaluation of molecular typing methods for Salmonella enterica serovar Typhimurium DT104 isolated in Germany from healthy pigs
}

\author{
Burkhard Malorny, Andreas Schroeter, Cornelia Bunge, \\ Bernhard Hoog, Antje Steinbeck, Reiner HelmutH* \\ Federal Institute for Health Protection of Consumers and Veterinary Medicine, \\ Diedersdorfer Weg 1, 12277 Berlin, Germany
}

(Received 24 July 2000; accepted 17 November 2000)

\begin{abstract}
The discriminatory power of four different DNA based typing methods was tested for the molecular subtyping of Salmonella Typhimurium phage type DT104 isolates. German DT104 strains $(n=133)$ originating from slaughter pigs were analysed by plasmid profiling, and 32 of them by pulsed-field gel electrophoresis (PFGE) using the restriction enzymes XbaI, SpeI or BlnI, random amplification of polymorphic DNA (RAPD) using 13 different primers and IS200 typing. A resulting subtyping scheme was obtained which is based on the most discriminatory power of the individual methods i.e. plasmid profiling and PFGE with all three enzymes. The index of discrimination obtained by the subtyping scheme was 0.909 closely approaching the maximum value of one. Although minor differences occurred in the molecular DNA pattern of single DT104 strains, a dominating subtyping pattern was observed confirming other studies which showed, that $S$. Typhimurium DT104 isolates are highly clonal.
\end{abstract}

RAPD / IS200 / PFGE / plasmid profiling / Salmonella Typhimurium DT104

Résumé - Évaluation de plusieurs méthodes de typage moléculaire de Salmonella enterica serovar Typhimurium DT104 isolées chez des porcs sains en Allemagne. Le pouvoir discriminant de quatre méthodes différentes basées sur le typage de l'ADN a été testé pour le sous-typage d'isolats de Salmonella Typhimurium DT104. Cent trente trois souches allemandes de DT104 provenant de porcs à l'abattoir ont été analysées par la méthode de profilage de plasmides, et 32 d'entre elles par électrophorèse sur gel en champ pulsé (PFGE) utilisant les enzymes de restriction XbaI, SpeI ou $B \ln \mathrm{I}$, par amplification aléatoire d'ADN polymorphe (RAPD) utilisant 13 amorces différentes, et par typage avec IS200. Un protocole de sous-typage, basé sur le plus fort pouvoir discriminant des méthodes individuelles, a été obtenu. Il s'agit du profilage de plasmides associé à l'électrophorèse sur gel en champ pulsé utilisant les trois enzymes de restriction. L'index de discrimination obtenu avec

* Correspondence and reprints

Tel.: (49) 308412 2233; fax: (49) 308412 2953; e-mail: r.helmuth@bgvv.de 
ce protocole de sous-typage était de 0,909 , proche de la valeur maximale de 1 . Bien que des différences mineures soient apparues dans les profils moléculaires de l'ADN des souches DT104, un profil dominant de sous-type a été observé, confirmant les résultats d'autres études ayant montré que les isolats de Salmonella Typhimurium étaient fortement clonaux.

amplification aléatoire d'ADN polymorphe / IS200 / profilage de plasmide / Salmonella Typhimurium DT104

\section{INTRODUCTION}

Traditional typing methods for salmonella isolates rely on serotyping which is based on the chemical structure of the lipopolysaccharide and flagelli [24]. For subtyping within a serotype, phage typing, based on the bacterial lysis due to specific typing phages, is used [3]. For many analyses, however, these methods are not discriminative enough and modern molecular DNA-based methods had to be introduced for typing of frequently encountered serotypes. Such techniques include plasmid profiling, ribotyping, biotyping, pulsed-field gel electrophoresis (PFGE), IS200 profiling and randomly amplified polymorphic DNA (RAPD). The high discriminatory power of DNA typing allows to differentiate related from unrelated strains isolated in a short period of time, especially strains isolated from an outbreak (for review see reference [23]).

Since 1990 increasing incidence of infections in both humans and animals caused by multiresistant $S$. Typhimurium phage type DT104 were reported in many European countries $[1,26,29]$ and in the USA [8]. Molecular studies have demonstrated that the resistance to $\beta$-lactams, aminoglycosides and sulfonamides are chromosomally encoded by two different integrons $[9,27]$. Resistance to tetracyclines and phenicols are in contrast located between the integrons [4]. DT104 initially emerged in cattle in 1988 in England and Wales [29]. Subsequently, the clone has been isolated from a large variety of livestock and other animals and can cause human infections via the food chain or direct animal contact [11, 21].

Molecular typing analyses indicated that DT104 isolates originating from different hosts and geographic origins are highly clonal $[7,15,26,30]$. The determination of plasmid profiles in DT104 isolates revealed that the majority of strains possess a single $60 \mathrm{MDa}$ plasmid and in some strains smaller plasmids between 5 and $1 \mathrm{MDa}$ as well [26, 30]. A study in nine Danish pig herds showed, that 93 DT104 strains except one shared an identical XbaI-PFGE pattern [6]

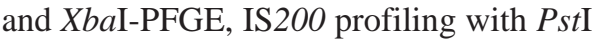
and ribotyping with $P v u I I$ from European DT104 isolates resulted in one common clonal type [26]. A combination of randomly amplified polymorphic DNA (RAPD) using two different 10 mer primers and subsequent restriction analysis indicated also a close relationship between DT104 strains [15].

Therefore, the aim of this study was to characterize the clonality of DT104 isolates originating from feces, lymphnodes and surface swabs of slaughter pig sampled in different abattoirs in Germany [18]. Possible molecular differences between single DT104 isolates will be detected by the application of several DNA based typing methods. Plasmid profiling, PFGE using different restriction enzymes, RAPD using 13 different primers and IS200 profiling were tested for their value to discriminate between single DT104 isolates. Although the discriminative index was close to one, the study demonstrated the wide prevalence of a predominating $S$. Typhimurium DT104 clone in slaughter pigs in Germany. 


\section{MATERIALS AND METHODS}

\subsection{Bacterial strains}

$S$. Typhimurium DT104 isolates $(n=$ 403) were obtained from seven abattoirs distributed all over Germany on ten weekly sampling occasions in February through June 1996 from surface swabs, fecal or lymph node material of freshly slaughtered pigs [18].

Serotyping was performed according to the Kauffmann White scheme [24] and phage typing was performed using the Anderson scheme as applied in the public health laboratory service in Colindale [3].

\subsection{Experimental procedure}

The aim of the study was to evaluate established, standard phenotypic and genotypic techniques for their discriminative power to subtype $S$. Typhimurium DT104 isolates originating from slaughter pig from seven different abattoirs obtained in a study on the prevalence of Salmonella in German pigs [18]. Initially all 403 isolates were tested for their susceptibility against antimicrobial agents. Among those, 133 isolates belonging to representative resistance phenotypes obtained in all abattoirs and originating from fecal, swab and lymphnode material were further differentiated by plasmid profiling. Finally 32 strains representing the various plasmid profiles were further analyzed by more elaborated molecular techniques like pulsed-field gel electrophoresis (PFGE), IS200 typing and randomly amplified polymorphic DNA-PCR (RAPD-PCR).

\subsection{Antimicrobial susceptibility test}

All DT104 isolates were tested for their susceptibility to 16 different antimicrobial agents by agar diffusion tests in accordance with the guidelines of the German Institute for Standards (DIN 5894 part 3) [12] with antibiotic disks (Oxoid Ltd., London, England). The antimicrobial agents used were: amikamycin $(30 \mu \mathrm{g})$, ampicillin $(10 \mu \mathrm{g})$, chloramphenicol (30 $\mu \mathrm{g})$, cefuroxim $(30 \mu \mathrm{g})$, colistinsulphate $(10 \mu \mathrm{g})$, enrofloxacin $(5 \mu \mathrm{g})$, furazolidone $(100 \mu \mathrm{g})$, gentamicin $(10 \mu \mathrm{g})$, kanamycin $(30 \mu \mathrm{g})$, nalidixic acid $(30 \mu \mathrm{g})$, neomycin $(10 \mu \mathrm{g})$, polymyxin B (300 I.E.), streptomycin $(25 \mu \mathrm{g})$, sulphamethoxazole-trimethoprim $(25 \mu \mathrm{g})$, sulphonamides $(300 \mu \mathrm{g})$ and tetracycline $(30 \mu \mathrm{g})$.

\subsection{Molecular typing techniques}

\subsubsection{Plasmid profile typing}

Plasmid DNA was isolated by the alkaline denaturation method described previously [17] with minor modifications. Electrophoresis of plasmid DNA was performed in $1 \times \mathrm{TBE}$ at $100 \mathrm{~V}$ for $2.5 \mathrm{~h}$ on $0.8 \%$ agarose gels, afterwards stained with ethidium bromide and photographed. The molecular weight standards were a supercoiled DNA ladder (Gibco BRL, Karlsruhe, Germany) and the plasmids R27 (112 MDa), R1 (62 MDa), RP4 (36 MDa), and ColE1 (4.2 MDa). Molecular sizes from plasmids were calculated as previously described [13].

\subsubsection{Randomly amplified polymorphic DNA (RAPD)}

It is well known, that RAPD patterns depend on many parameters like $\mathrm{MgCl}_{2}$ and $\mathrm{KCl}$ concentrations, template concentration and the thermal cycling protocol [14]. We got the most reliable and well-separated fragments with a two step thermal cycling protocol including $20^{\circ} \mathrm{C}$ and $30^{\circ} \mathrm{C}$ annealing temperature as well as a $3 \mathrm{mM} \mathrm{MgCl}$ and $50 \mathrm{mM} \mathrm{KCl}$ concentration for each reaction. The inclusion of $1 \mu \mathrm{g} \cdot \mu \mathrm{L}^{-1} \mathrm{BSA}$ in the RAPD reaction strengthened weaker bands but did not influence the overall pattern.

Thirteen 10-mer primers were chosen for typing $S$. Typhimurium DT104 strains. 
Twelve primers were previously described: 23L, OPB17, OPA4, OPB6 and OPB 15 [19], OPG08, OPH13, OPG04, OPG10 and OPH04 [20], 1283 and 1254 [2]. Primer OPB15/B was designed on the basis of the sequence of OPB 15 containing at the $5^{\prime}$ and 3' end a variable nucleotide $\mathrm{A}, \mathrm{C}, \mathrm{G}$ or $\mathrm{T}$. The genomic DNA as template for RAPDPCR was prepared as follows: the cells of $1 \mathrm{~mL}$ overnight broth culture were collected by centrifugation $(15000 \times g, 10 \mathrm{~min})$, resuspended in $300 \mu \mathrm{L}$ of sterile distilled water and boiled $(10 \mathrm{~min})$ in a water bath. After centrifugation $(15000 \times g, 10 \mathrm{~min})$ $5 \mu \mathrm{L}$ of supernatant containing DNA was used as a template in the RAPD-PCR reaction. Amplification reactions were performed in volumes of $25 \mu \mathrm{L}$ containing $10 \mathrm{mM}$ Tris- $\mathrm{HCl}, \mathrm{pH} 8.3,50 \mathrm{mM} \mathrm{KCl}$, $3 \mathrm{mM} \mathrm{MgCl} 2,0.001 \%$ gelatin, $200 \mu \mathrm{M}$ (each) dATP, dCTP, dGTP and dTTP, 25 pmol primer, $25 \mu \mathrm{g}$ BSA, 50 ng genomic DNA and 1.5 units Taq DNA polymerase (Perkin Elmer Biosystems, Weiterstadt, Germany). A Perkin Elmer GenAmp 2400 thermal cycler was used for amplification. The cycling program was $1 \mathrm{~min}$ at $94{ }^{\circ} \mathrm{C}$, six cycles at $94{ }^{\circ} \mathrm{C}$ for $30 \mathrm{~s}, 20^{\circ} \mathrm{C}$ for $30 \mathrm{~s}$, $72{ }^{\circ} \mathrm{C}$ for $1 \mathrm{~min}$ and 35 cycles at $94{ }^{\circ} \mathrm{C}$ for $30 \mathrm{~s}, 30{ }^{\circ} \mathrm{C}$ for $30 \mathrm{~s}, 72{ }^{\circ} \mathrm{C}$ for $1 \mathrm{~min}$. Finally an incubation at $72{ }^{\circ} \mathrm{C}$ for 4 min was performed. After PCR $5 \mu \mathrm{L}$ amplification products were analyzed by electrophoresis on $2 \%$ agarose gels (Gibco BRL) and detected by staining with ethidium bromide. Faint amplicons occurring in RAPD patterns were excluded from the analysis.

\subsubsection{Pulsed-field gel electrophoresis (PFGE)}

Pulsed-field gel electrophoresis after digestion of genomic DNA with SpeI, XbaI and BlnI from Salmonella strains resulted in suitable numbers of well-separated fragments $[25,28,31]$. These restriction enzymes were therefore chosen for further subtyping of the DT104 isolates.
Cells grown on Luria-Bertani agar plates for $16 \mathrm{~h}$ were suspended in phosphate buffered saline $\left(10 \mathrm{~mL}, 5 \times 10^{8}\right.$ cells $\left.\cdot \mathrm{mL}^{-1}\right)$, centrifuged and resuspended in $1 \mathrm{~mL}$ of $1 \%$ agarose (ImBed LMP agarose, New England Biolabs, Schwalbach, Germany). $0.1 \mathrm{~mL}$ plugs were chilled in plastic moulds (BioRad, München, Germany) for $20 \mathrm{~min}$. The plugs were incubated overnight at $37^{\circ} \mathrm{C}$ in $50 \mathrm{~mL}$ lysis buffer $\left(1 \mu \mathrm{g} \cdot \mathrm{mL}^{-1}\right.$ RNAse, 1\% Sarkosyl, $6 \mathrm{mM}$ Tris- $\mathrm{HCl}, 100 \mathrm{mM}$ EDTA, pH 8.0), and overnight at $50^{\circ} \mathrm{C}$ in $2.5 \mathrm{~mL}$ of ESP solution (1\% Sarkosyl, $1 \mathrm{mg} \cdot \mathrm{mL}^{-1}$ proteinase $\mathrm{K}, 500 \mathrm{mM}$ EDTA, $\mathrm{pH}$ 8.0). The plugs were washed four times in $50 \mathrm{~mL}$ of TE buffer $\mathrm{pH} 8.0$ at $37^{\circ} \mathrm{C}$ for $30 \mathrm{~min}$ and could be stored at $4{ }^{\circ} \mathrm{C}$ up to 3 months. Quartered plugs were equilibrated with $0.3 \mathrm{~mL}$ of digestion buffer for $15 \mathrm{~min}$ and after replacing the buffer incubated overnight at $37^{\circ} \mathrm{C}$ with 10 units of XbaI (New England Biolabs), 5 units of SpeI (New England Biolabs) or 5 units of $B \ln \mathrm{I}$ (Roche Diagnostics, Mannheim, Germany). The plugs were melted at $65^{\circ} \mathrm{C}$ and loaded on $1 \%$ agarose gels (Seakem GTG agarose, FMC BioProducts, Maine, USA). Electrophoresis (BioRad, CHEF-DRII) was performed in $0.5 \times \mathrm{TBE}$ at $10^{\circ} \mathrm{C}$, at $200 \mathrm{~V}$ with pulse ramping from 2 to $40 \mathrm{~s}$ over $24 \mathrm{~h}$ (SpeI), 5 to $50 \mathrm{~s}$ over $24 \mathrm{~h}(\mathrm{XbaI})$ or 8 to $80 \mathrm{~s}$ over $25 \mathrm{~h}(B \ln \mathrm{I})$. The gels were stained with ethidium bromide and photographed under UV light. Molecular weight standards were lambda concatemers Mid Range II Markers (New England Biolabs). For analysis a fragment size range from $750 \mathrm{~kb}$ to $30 \mathrm{~kb}$ was considered.

\subsubsection{IS200 typing}

Digoxigenin (DIG)-labeled IS200 probes (557 bp) were synthesized by PCR amplification ( 30 cycles of $1 \mathrm{~min}$ at $94{ }^{\circ} \mathrm{C}, 1 \mathrm{~min}$ at $63{ }^{\circ} \mathrm{C}, 1 \mathrm{~min}$ at $72{ }^{\circ} \mathrm{C}$; final incubation at $72{ }^{\circ} \mathrm{C}$ for $4 \mathrm{~min}$ ) with genomic DNA of $S$. Typhimurium strain LT2 as template. The primers for amplification IS200-L2 and IS200-R2 were described previously [10]. 
Amplification reactions were performed in volumes of $50 \mu \mathrm{L}$ containing $10 \mathrm{mM}$ Tris$\mathrm{HCl}, \mathrm{pH} 8.3,50 \mathrm{mM} \mathrm{KCl}, 1.5 \mathrm{mM} \mathrm{MgCl}$, $0.001 \%$ gelatin, $200 \mu \mathrm{M}$ (each) dATP, dCTP, dGTP and dTTP, 10 pmol of each primer, $50 \mu \mathrm{g}$ BSA, 50 ng genomic DNA and 1.5 units Taq DNA polymerase (Perkin Elmer Biosystems). The PCR product was DIG labeled with the random primed labeling hexanucleotide mix (Roche Diagnostics) according to the manufacturers protocol.

Genomic DNA isolation for IS200 typing was performed as previously described [5]. One microgram of genomic DNA was digested with $P s t \mathrm{I}$ according to the manufacturers' instructions and separated on $1 \%$ agarose gels in $1 \times \mathrm{TBE}$ at $45 \mathrm{~V}$ for $19 \mathrm{~h}$. The gels were stained with ethidium bromide and photographed. DNA was transferred from agarose gels to Hybond $\mathrm{N}$ nylon membranes (Amersham Pharmacia, Freiburg, Germany) in $10 \times$ SSC using a vacuum blotter (model 785, BioRad) and hybridized to the Digoxigenin-labeled IS200 fragment at $42{ }^{\circ} \mathrm{C}$ overnight in a solution containing $50 \%$ formamide. Unbound IS200 probe was removed by washing the membranes twice with $2 \times \mathrm{SSC}$ and $0.1 \%$ SDS at room temperature and twice with $0.1 \times \mathrm{SSC}$ and $0.1 \%$ SDS at $68{ }^{\circ} \mathrm{C}$. The bound probe was recognized by a colorimetric assay as described in the DIG DNA Detection Kit (Roche Diagnostics).

\subsection{Calculation of discriminatory power}

The discriminatory power of the different molecular typing methods was calculated by determining the indices of discrimination (D values) according to Hunter and Gaston [16]. These values calculate the probability that two strains from the test population will be classified into different typing groups. The lower the index value is, the less discriminative is the typing method.

\section{RESULTS}

\subsection{Susceptibility to antimicrobial agents}

Among the 403 DT104 strains originating from slaughter pigs $94 \%$ were identified as multiresistant. Among them 367 (91\%) of the strains exhibited only the typical pentaresistance to ampicillin (A), chloramphenicol (C), streptomycin (S), sulphonamides $(\mathrm{Su})$ and tetracycline (T) (= R-type ACSSuT) described for DT104 [29, 30]. Twenty-four $(6 \%)$ of the strains investigated were sensitive to all sixteen antimicrobial agents tested.

\subsection{Molecular typing of pig isolates}

Of the 403 isolates, 133 were initially characterized for their plasmid profile (Tab. I). The isolates selected represented arbitrary samples distributed evenly over the seven abattoirs and samplings [18]. Thirty-two representative strains were selected from the 133 plasmid typed DT104 isolates for the application of other molecular typing techniques. Table II describes the genotypes obtained.

\subsubsection{Plasmid profile patterns}

All 133 strains possessed at least one to four plasmids which resulted in eight different plasmid profile patterns (A to H) (Fig. 1, Tab. I). A 60 MDa plasmid was observed in seven plasmid profile patterns which represents the typical serovar specific virulence plasmid (pRQ28) [13] of $S$. Typhimurium. Plasmid pattern A (24\%), B (20\%) and C (47\%) predominated and represented $92 \%$ of the 133 isolates. The ten strains belonging to the pattern D, E, F and G were always sensitive to antimicrobial agents (Tab. I).

The results showed that some of the DT104 isolates of the slaughter pigs could already be discriminated by their plasmid profiles. 
Table I. Plasmid profile patterns and resistance or sensitivity to antimicrobial agents of 133 DT104 isolates originating from slaughter pigs.

\begin{tabular}{lccc}
\hline Plasmid size (MDa) & Plasmid profile pattern & \multicolumn{2}{c}{ Number of strains } \\
\cline { 3 - 4 } & & Resistant & Sensitive \\
\hline 60 & A & 24 & 8 \\
$60,1.4$ & B & 25 & 2 \\
$60,2.2,1.4$ & $\mathrm{C}$ & 63 & 0 \\
$60,4,2.4,1$ & $\mathrm{D}$ & 0 & 5 \\
2.8 & $\mathrm{E}$ & 0 & 1 \\
$68,60,55,1.4$ & $\mathrm{~F}$ & 0 & 2 \\
$60,4.6$ & $\mathrm{G}$ & 0 & 0 \\
60,20 & $\mathrm{H}$ & 113 & 20 \\
Total number & 8 & & 0 \\
\hline
\end{tabular}

Note: Some of the patterns correlate to the ones described by Threlfall et al. [30] namely (our nomenclature Threlfall's nomenclature) $\mathrm{A}=\mathrm{A}, \mathrm{B}=\mathrm{C}, \mathrm{D}=\mathrm{G}, \mathrm{G}=\mathrm{E}$.

\subsubsection{IS200 typing}

Four distinct patterns could be detected within the 32 selected DT104 strains (Fig.1, Tab. II). Pattern 1 occurred in 27 isolates whereas pattern 2 and 4 were observed in two strains each (strains: 62L129, 62L142, genotype 15 and $310 \mathrm{~K} 21,310 \mathrm{~L} 23$, genotype 2 ) and pattern 3 in one strain only (strain 67L10, genotype 16). All strains belonging to the IS200 patterns 2 to 4 were sensitive to antimicrobial agents. The number of IS200 elements varied between eleven in pattern 1 and six in pattern 2 (Fig. 1).

\subsubsection{PFGE typing}

Seven distinct pulsed-field gel electrophoresis patterns were observed with SpeI (designated S1 to S7) and BlnI (B1 to B7) (Tab. II). XbaI digestions resulted in four different patterns (X1 to X4) among the 32 isolates originating from pig. The patterns $\mathrm{S} 1, \mathrm{X} 1$ and B1 were most predominantly observed in 69\% (SpeI), 81\% (XbaI) or $63 \%(B \ln \mathrm{I})$ of the cases and selected as reference patterns. Pattern S1 (SpeI) contained 21 fragments ranging in sizes from 20 to $440 \mathrm{~kb}$ (Fig. 1). XbaI produced 15 fragments (pattern $\mathrm{X} 1$ ) ranging in sizes from 20 to $700 \mathrm{~kb}$ and $B \ln \mathrm{I} 10$ fragments (pattern B1) ranging in sizes from 20 to $750 \mathrm{~kb}$ (data not shown). In most of the cases pulsed-field gel patterns of one restriction enzyme differed by one to three fragments only, indicating a close relationship of the strains. In some cases (five strains, genotype 2, 15 and 16) the PFGE pattern differed for each restriction enzyme used (Tab. II) indicating a different common ancestor. Thirteen strains showed PFGE patterns, where only one out of the three restriction enzymes caused a negligible different PFGE pattern indicating a common ancestor.

\subsubsection{RAPD typing}

The reproducibility of RAPD was tested with 10 different genomic DNA preparations from one strain of $S$. Typhimurium DT104 (51K61) and one primer (23L). In addition, 10 different strains isolated in one abattoir containing identical plasmid profiles and resistance patterns were tested in RAPD with primer $23 \mathrm{~L}$ and OPB15/B. The resulting patterns were identical (data not shown). This showed the high reproducibility of RAPD under the conditions used.

RAPD was carried out with the 32 representative DT104 strains. The patterns except one (OPG08) consisted of 6 to 
Table II. Genotypes of 32 representative DT104 isolates originating from slaughter pigs.

\begin{tabular}{|c|c|c|c|c|c|c|c|c|}
\hline \multirow[t]{2}{*}{ Genotype } & \multirow{2}{*}{$\begin{array}{l}\text { No. of } \\
\text { strains }^{\mathrm{a}}\end{array}$} & \multirow[t]{2}{*}{ Resistance $^{b}$} & \multirow{2}{*}{$\begin{array}{l}\text { Plasmid } \\
\text { profile }\end{array}$} & \multicolumn{3}{|c|}{ PFGE pattern } & \multirow{2}{*}{$\begin{array}{l}\text { IS200 pattern } \\
\text { (no. of } \\
\text { bands) }\end{array}$} & \multirow{2}{*}{$\begin{array}{l}\text { RAPD } \\
\text { pattern }^{c}\end{array}$} \\
\hline & & & & SpeI & $X b a \mathrm{I}$ & $B \ln \mathrm{I}$ & & \\
\hline 1 & 8 & ACSSuT & A & 1 & 1 & 1 & $1(11)$ & 111111111111 \\
\hline 2 & 2 & sensitive & A & $5^{*}$ & $2 *$ & $4 *$ & $4(10)$ & 354112623322 \\
\hline 3 & 2 & ACSSuT & B & 1 & 1 & 2 & $1(11)$ & 211111112121 \\
\hline 4 & 2 & ACSSuT & B & 1 & 1 & 2 & $1(11)$ & 211211112121 \\
\hline 5 & 1 & ACSSuT & B & 7 & 1 & 1 & $1(11)$ & 111111111111 \\
\hline 6 & 2 & ACSSuT & B & 1 & 1 & 1 & $1(11)$ & 111111111111 \\
\hline 7 & 1 & $\mathrm{CSSu}$ & B & 1 & 1 & 7 & $1(11)$ & 141111111111 \\
\hline 8 & 1 & ACSSuT & B & 1 & 1 & 7 & $1(11)$ & 141111111111 \\
\hline 9 & 1 & ACSSuT & B & 1 & 1 & 3 & $1(11)$ & 111111111111 \\
\hline 10 & 1 & ACSSuT & B & 4 & 1 & 1 & $1(11)$ & 116111111111 \\
\hline 11 & 1 & sensitive & B & 4 & 1 & 1 & $1(11)$ & 116111511111 \\
\hline 12 & 2 & ACSSuT & $\mathrm{C}$ & 1 & 1 & 1 & $1(11)$ & 111111111111 \\
\hline 13 & 1 & ACSSuT & $\mathrm{C}$ & 1 & 1 & 1 & $1(11)$ & 131111111111 \\
\hline 14 & 1 & ACSSuT & $\mathrm{C}$ & 1 & 1 & 1 & $1(11)$ & 111111311111 \\
\hline 15 & 2 & sensitive & D & $5^{*}$ & $2 *$ & $5^{*}$ & $2(6)$ & 322111222222 \\
\hline 16 & 1 & sensitive & $\mathrm{E}$ & 3 & $3 *$ & 6 & $3(10)$ & 373111134233 \\
\hline 17 & 1 & sensitive & $\mathrm{F}$ & 6 & 1 & 1 & $1(11)$ & 165111411111 \\
\hline 18 & 1 & sensitive & G & 2 & 4 & 1 & $1(11)$ & 111111111111 \\
\hline 19 & 1 & ACSSuT & $\mathrm{H}$ & 1 & 1 & 1 & $1(11)$ & 411111112121 \\
\hline
\end{tabular}

* Difference in more than three bands in respect to reference pattern.

a The following strain designations belong to the genotypes (genotype-strain designations): 1-51K61, 51O20, 22O42, 24K8, 65K163, 16O3, 26K121, 610O12; 2-310K21, 310L23; 3-32K112, 24K200; 4-32L126, 32O151; 5-13K195; 6-24O137, 110L54; 7-55L34; 8-55O93; 9-26K117; 10-110K11;11-110O138; 12-12O194, 16K51;1354K91; 14-17O134; 15-62L129, 62L142; 16-67L10; 17-110L44; 18-310K100; 19-51O47. The first number encodes the abattoir, the second number the week of isolation, the letter at the third position indicates the material of isolation from the slaughtered pigs, $\mathrm{K}$ (fecal), O (surface swab), L (lymphnode). The following number designates each individual slaughter pig.

${ }^{\mathrm{b}} \mathrm{A}$ (ampicillin), C (chloramphenicol), S (streptomycin), Su (sulphonamides) and T (tetracycline).

${ }^{c}$ Each number defines a certain RAPD pattern in the order of the following primers: 23L-OPB15/B-OPB151283-OPG10-OPH04-OPH13-OPB17-OPA4-OPG04-OPB6-1254.

12 bands ranging from about $3 \mathrm{~kb}$ to 200 bp. The primer OPG08, which is applicable for $S$. Enteritidis subtyping [20] generated only a $2 \mathrm{~kb}$ fragment and was therefore excluded from further studies. The number of patterns of each primer ranged between one and seven (OPG10: one pattern; 1283, OPH04: two; OPB17, OPG04, OPB6, 1254: three; 23L, OPA4: four; OPB15, OPH13: six; OPB15/B: seven) and patterns generated by one primer differed mostly in one or two bands. The 12 primers differentiated the 32 strains in 13 typing patterns. Because of their low or identical discriminatory power, the primers OPG10,
1254, OPG04, OPA4, OPH04 could be excluded from the analysis without influencing the number of patterns.

RAPD results correlated with the results of the other molecular typing methods described above. In addition, the patterns of some primers correlated with the patterns derived from PFGE. For example four strains (Tab. II: strains 32K112, 32L126, $32 \mathrm{O} 151$ and 24K200, genotypes 3 and 4) possessed corresponding patterns generated by primer $23 \mathrm{~L}$ and by $B \ln \mathrm{I}-\mathrm{PFGE}$ (pattern B2). Two other strains shared unique patterns of primer OPB $15 / \mathrm{B}$ and $B \ln \mathrm{I}-$ PFGE B7. 

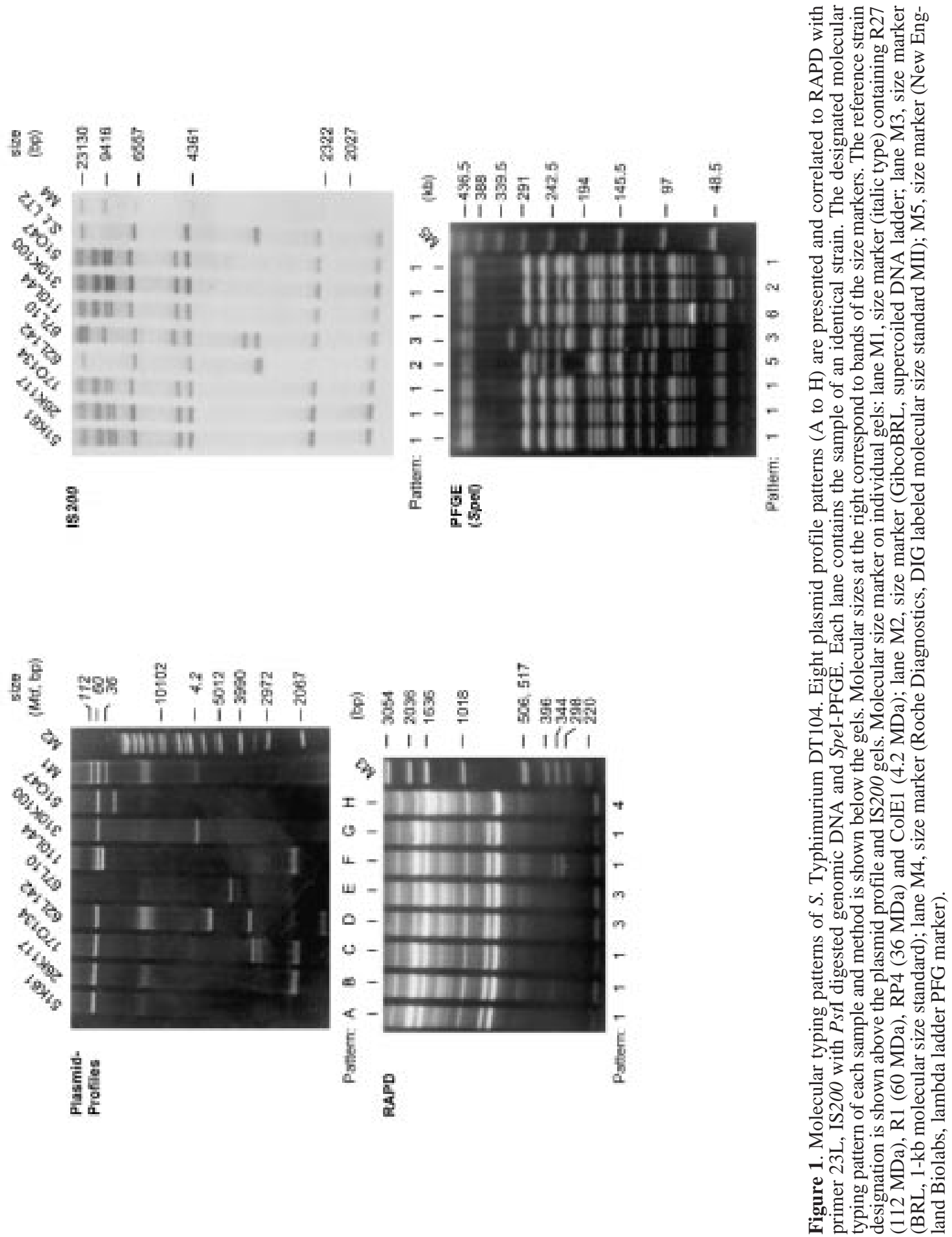

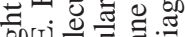
圷薄导 品 可要过

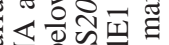

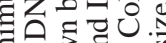
․․ำ

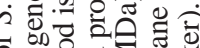

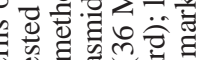
.0 -

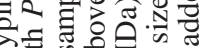

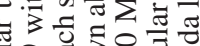

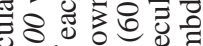
응

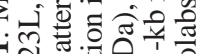

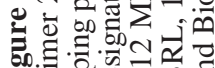

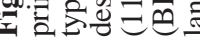


Table III. Discrimination indices of molecular typing methods applied to 32 DT104 isolates.

\begin{tabular}{lcc}
\hline Method & $\begin{array}{c}\text { Number of } \\
\text { types }\end{array}$ & $\begin{array}{c}\text { Discrimination } \\
\text { index }\end{array}$ \\
\hline Plasmid profiles & 8 & 0.762 \\
PFGE (SpeI) & 7 & 0.520 \\
PFGE (XbaI) & 4 & 0.332 \\
PFGE (BlnI) & 7 & 0.599 \\
PFGE (SpeI, XbaI, BlnI) & 12 & 0.796 \\
IS200 (PstI) & 4 & 0.288 \\
RAPD (23L/OPB15/B) & 9 & 0.673 \\
RAPD (12 primers) & 13 & 0.778 \\
Plasmid profiles/PFGE (SpeI) & 11 & 0.853 \\
Plasmid profiles/PFGE (XbaI) & 9 & 0.794 \\
Plasmid profiles/PFGE (BlnI) & 12 & 0.893 \\
Plasmid profiles/PFGE (SpeI, XbaI, BlnI) & 14 & 0.909 \\
Plasmid profiles/RAPD (23L) & 10 & 0.859 \\
Plasmid profiles/RAPD (OPB15/B) & 11 & 0.841 \\
Plasmid profiles/PFGE (BlnI)/RAPD (OPB15) & 13 & 0.905 \\
\hline
\end{tabular}

\subsection{Discriminatory power and application of a subtyping scheme}

The calculated indices for each individual typing method and the method combinations are given in Table III. Plasmid profiles possessed the highest discriminatory power among the 32 isolates followed by RAPD in combination with the two most discriminatory primers 23L and OPB15/B (Tab. III) as well as PFGE with the restriction enzyme $B \ln$ I. The very low index of IS200 typing indicates that this typing method is not a suitable tool for subtyping DT104 isolates. Nevertheless, each molecular typing method per se seems to be not discriminative enough. The combination of the methods with the highest $\mathrm{D}$ values resulted in better discrimination. Acceptable levels of discrimination $(>0.9)$ were obtained by the combination of plasmid profiling, PFGE with $B \ln I$ and RAPD with primer OPB15. Alternatively, the combination of plasmid profiles and PFGE patterns from all three restriction enzymes resulted in an index of 0.909 .

\section{DISCUSSION}

In this study, the efficiencies of four different DNA based typing methods were evaluated for subtyping German $S$. Typhimurium phage type DT104 isolates. DT104 strains $(n=133)$ originating from slaughtered pigs were subject to plasmid profiling, and 32 to PFGE, RAPD and IS200 typing.

Plasmid profiling of the 32 pig isolates resulted in an index of discrimination of 0.762 . Sixty to $70 \%$ of the isolates had identical XbaI, SpeI or BlnI PFGE-patterns with an index of discrimination of 0.332 for $X b a \mathrm{I}$, 0.520 for SpeI and 0.599 for BlnI. RAPD using 12 different primers in combination detected 13 different genotypes resulting in an index of discrimination of 0.778 . Individual primers showed only a moderate discriminatory power. IS200 typing of the 32 isolates revealed only four different patterns $(D=0.288)$. The $D$ values confirm that the molecular typing methods tested have different discriminatory power. A theoretical maximum value of one indicates a $100 \%$ discrimination probability for each strain tested. According to our results, plas- 
mid profiling alone is the most discriminatory method. In addition it is fast, easy to perform and reproducible and should consequently be the first method of choice for subtyping DT104 isolates.

The combination of different typing methods increased the index of discrimination and resulted in a useful subtyping scheme for DT104 isolates. The combination of plasmid profiling with PFGE patterns from XbaI, SpeI and $B \ln \mathrm{I}$ digestions resulted in a maximum of discrimination. Therefore, we recommend these methods for subtyping of DT104 in the future. Similar results were reported for the serotype $S$. Hadar [31]. Alternatively, RAPD can be applied for the discrimination of DT104 isolates using at least the primers $23 \mathrm{~L}$ and OPB15/B in combination. The disadvantage of RAPD is its sensitivity to several parameters and lack of comparability of data obtained in different laboratories. The discriminatory power of RAPD depends mainly on the specificity of the primer. Among the 32 isolates from pig origin OPB15/B, 23L, OPB15 and OPH13 were the most discriminative primers. It is necessary that the proposed subtyping scheme will be applied to further DT104 isolates obtained from other livestock species in order to confirm the observed discrimination indices.

The study has shown that in general only minor differences occur in the DNA pattern of single DT104 strains isolated from slaughter pigs. These clonal subtypes most likely represented variants of the predominating clone. Such variants did not establish successfully and did not lead to a clonal replacement within the ten weeks and among the abattoirs. Clonal replacement within a short period of time is possible as described for an epidemic clonal group of Neisseria meningitidis [22]. The data presented here in contrast show that the spread of DT104 from German pigs is highly clonal and stable.

\section{REFERENCES}

[1] Aarestrup F.M., Jensen N.E., Baggesen D.L., Clonal spread of tetracycline-resistant Salmonella typhimurium in Danish dairy herds, Vet. Rec. 140 (1997) 313-314.

[2] Akopyanz N., Bukanov N.O., Westblom T.U., Kresovich S., Berg D.E., DNA diversity among clinical isolates of Helicobacter pylori detected by PCR-based RAPD fingerprinting, Nucleic Acids Res. 20 (1992) 5137-5142.

[3] Anderson E.S., Ward L.R., de Saxe M.J., de Sa J.D.H., Bacteriophage-typing designations of Salmonella typhimurium, J. Hyg. 78 (1977) $297-$ 300.

[4] Arcangioli M.A., Leroy-Sétrin S., Martel J.L., Chaslus-Dancla E., A new chloramphenicol and florfenicol resistance gene flanked by two integron structures in Salmonella typhimurium DT104, FEMS Microbiol. Lett. 174 (1999) 327332.

[5] Ausubel F.M., Brent R., Kingstone R.E., Moore D.D., Seidman J.G., Smith J.A., Struhl K., Current protocols in molecular biology, John Wiley \& Sons, Massachusetts, USA, 1997.

[6] Baggesen D.L., Aarestrup F.M., Characterisation of recently emerged multiple antibioticresistant Salmonella enterica serovar Typhimurium DT104 and other multiresistant phage types from Danish pig herds, Vet. Rec. 143 (1998) 95-97.

[7] Baggesen D.L., Sandvang D., Aarestrup F.M., Characterization of Salmonella enterica serovar Typhimurium DT104 isolated from Denmark and comparison with isolates from Europe and the United States, J. Clin. Microbiol. 38 (2000) 1581-1586.

[8] Besser T.E., Gay C.C., Gay J.M., Hancock D.D., Rice D., Pritchett L.C., Erickson E.D., Salmonellosis associated with Salmonella typhimurium DT104 in the USA, Vet. Rec. 140 (1997) 75.

[9] Briggs C.E., Fratamico P.M., Molecular characterization of an antibiotic resistance gene cluster of Salmonella typhimurium DT104, Antimicrob. Agents Chemother. 43 (1999) 846-849.

[10] Burnens A.P., Stanley J., Sechter I., Nicolet J., Evolutionary origin of a monophasic Salmonella serovar, 9,12:1,v:-, revealed by IS200 profiles and restriction fragment polymorphisms of the fljB gene, J. Clin. Microbiol. 34 (1996) 16411645.

[11] Davies A., O'Neill P., Towers L., Cooke M., An outbreak of Salmonella typhimurium DT104 food poisoning associated with eating beef, Communicable Disease Report 6 (1996) R159-R162.

[12] Deutsches Institut für Normung e.V., Methods for the determination of susceptibility of pathogens (except mycobacteria) to antimicrobial agents; agar diffusion test DIN 58940 part 3, Berlin, 1989. 
[13] Helmuth R., Stephan R., Bunge C., Hoog B., Steinbeck A., Bulling E., Epidemiology of virulence-associated plasmids and outer membrane protein patterns within seven common Salmonella serotypes, Infect. Immun. 48 (1985) 175-182.

[14] Hilton A.C., Banks J.G., Penn C.W., Optimization of RAPD for fingerprinting Salmonella, Lett. Appl. Microbiol. 24 (1997) 243-248.

[15] Hilton A.C., Penn C.W., Restriction enzyme analysis of randomly amplified polymorphic DNA amplicons of Salmonella enterica ser. Enteritidis PT4 and Typhimurium DT104, Lett. Appl. Microbiol. 27 (1998) 158-162.

[16] Hunter P.R., Gaston M.A., Numerical index of the discriminatory ability of typing systems: an application of Simpson`s index of diversity, J. Clin. Microbiol. 26 (1988) 2465-2466.

[17] Kado C.I., Liu S.T., Rapid procedure for detection and isolation of large and small plasmids, $\mathrm{J}$. Bacteriol. 145 (1981) 1365-1373.

[18] Käsbohrer A., Protz D., Helmuth R., Nöckler K., Blaha T., Conraths F.J., Geue L., Salmonella in slaughter pigs of German origin: an epidemiological study, Eur. J. Epidemiol. 16 (2000) 141146.

[19] Lin A.W., Usera M.A., Barrett T.J., Goldsby R.A., Application of random amplified polymorphic DNA analysis to differentiate strains of Salmonella enteritidis, J. Clin. Microbiol. 34 (1996) 870-876.

[20] Millemann Y., Lesage M.-C., Chaslus-Dancla E., Lafont J.-P., Value of plasmid profiling, ribotyping, and detection of IS200 for tracing avian isolates of Salmonella typhimurium and S. enteritidis, J. Clin. Microbiol. 33 (1995) 173-179.

[21] Mølbak K., Baggesen D.L., Aarestrup F.M., Ebbesen J.M., Engberg J., Frydendahl K., Gerner-Smidt P., Petersen A.M., Wegener H.C., An outbreak of multidrug-resistant, quinoloneresistant Salmonella enterica serotype typhimurium DT104, N. Engl. J. Med. 341 (1999) 1420-1425.

[22] Morelli G., Malorny B., Müller K., Seiler A., Wang J.F., del Valle J., Achtman M., Clonal descent and microevolution of Neisseria menin- gitidis during 30 years of epidemic spread, Mol. Microbiol. 25 (1997) 1047-1064.

[23] Olsen J.E., Molecular typing of Salmonella, in Wray C., Wray A. (Eds.), Salmonella in domestic animals, CABI Publishing, Oxon, 2000, pp. 429-446.

[24] Popoff M.Y., Minor L.L. Antigenic formulas of the Salmonella serovars, WHO Collaborating Centre for Reference and Research on Salmonella, Institut Pasteur, Paris, France, 1997.

[25] Powell N.G., Threlfall E.J., Chart H., Rowe B., Subdivision of Salmonella enteritidis PT 4 by pulsed-field gel electrophoresis: Potential for epidemiological surveillance, FEMS Microbiol. Lett. 119 (1994) 193-198.

[26] Prager R., Liesegang A., Rabsch W., Gericke B., Thiel W., Voigt W., Helmuth R., Ward L., Tschäpe H., Clonal relationship of Salmonella enterica serovar typhimurium phage type DT104 in Germany and Austria, Zentralbl. Bakteriol. 289 (1999) 399-414.

[27] Sandvang D., Aarestrup F.M., Jensen L.B., Characterisation of integrons and antibiotic resistance genes in Danish multiresistant Salmonella enterica Typhimurium DT104, FEMS Microbiol. Lett. 160 (1998) 37-41.

[28] Thong K.-L., Ngeow Y.-F., Altwegg M., Navaratnam P., Pang T., Molecular analysis of Salmonella enteritidis by pulsed- field gel electrophoresis and ribotyping, J. Clin. Microbiol. 33 (1995) 1070-1074.

[29] Threlfall E.J., Frost J.A., Ward L.R., Rowe B., Epidemic in cattle and humans of Salmonella typhimurium DT104 with chromosomally integrated multiple drug resistance, Vet. Rec. 134 (1994) 577.

[30] Threlfall E.J., Hampton M.D., Schofield S.L., Ward L.R., Frost J.A., Rowe B., Epidemiological application of differentiating multiresistant Salmonella typhimurium DT104 by plasmid profile, Communicable Disease Report 6 (1996) R155-R159.

[31] Weide-Botjes M., Kobe B., Lange C., Schwarz S., Molecular typing of Salmonella enterica subsp. enterica serovar Hadar: evaluation and application of different typing methods, Vet. Microbiol. 61 (1998) 215-227. 